\title{
Examining Causality Relationships among Energy Consumption, Economic Growth and Islamic Banking System Performance in Jordan
}

\author{
Mohammad Salem Oudat ${ }^{1}$, Nursilah Ahmad $^{1} \&$ Mohamad Yazis $^{1}$ \\ ${ }^{1}$ Faculty of Economics and Muamalat, Universiti Sains Islam Malaysia (USIM), Malaysia \\ Correspondence: Mohammad Salem Oudat, Faculty of Economics and Muamalat, Universiti Sains Islam \\ Malaysia (USIM), Bandar Baru Nilai, 71800 Nilai, Negeri Sembilan, Malaysia. E-mail: \\ mohammad.oudat@yahoo.com
}

Received: March 5, 2015

Accepted: March 24, 2015

Online Published: May 25, 2015

doi:10.5539/ijef.v7n6p116

URL: http://dx.doi.org/10.5539/ijef.v7n6p116

\begin{abstract}
Various studies have been conducted to examine the causal relationship between economic growth and energy consumption among the countries that export and import energy sources but the discussions on the causal relationship between Islamic banking system performance and energy consumption are still lacking. The first aim of this paper is to provide some clarifications on the causal relationship between economic growths, GDP is used as a proxy of Jordan's economic growth and energy consumption, and also between Islamic banking system performances, and Murabaha is used as a proxy of Jordanian Islamic Bank performance and energy consumption. The second aim is to explore how far the Islamic banking system direction from the economic growth direction when affected by some macroeconomic variables such as energy consumption. Jordan has been chosen as the country under study because it heavily relied on imported energy sources to meet its needs. In order to analyze the long and short-run relationship, the annual time series data were used by employing the autoregressive distributed lag model (ARDL). Meanwhile, the Augmented Dickey Fuller (ADF) (1987) and the Ng-Perron (2001) were used for stationary test. Additionally, the Bounds F-statistics test was employed for testing co-integration among the variables. The ARDL approach was used to analyze the long-run and short-run relationships and for exploring the causal relationship among variables, the Granger causality test was employed. Results from the analyses show that the economic growth and energy consumption as well between Islamic banking system performance and energy consumption indicate unidirectional causal relationships but not vice versa. Another main finding is that Islamic banking system direction moves with the same economic growth direction in Jordan when affected by the energy consumption.
\end{abstract}

Keywords: energy consumption, GDP, Murabaha, Granger causality, Jordan

\section{Introduction}

Energy sources are an active element that helps the producing countries to exist among the political and economic powers globally. Thus, energy sources are an important economic pillar of a country. Somehow, it is also energy sources that have clearly become the primary reason for most wars that have recently occurred, such as the Iraq war in 2005. Nonetheless, the rise in the prices of energy sources by the oil and gas producing countries has affected the importing countries such as Jordan, weakening the economies of these importing countries.

Like some countries, Jordan also depends on other countries to meet its oil and gas needs. For instance, Jordan has relied on the oil imports from Iraq for a long time, and more recently from Saudi Arabia, as well as gas from Egypt. Recently, due to political situation in Egypt, Jordan has chosen Qatar to be its new gas supplier. Importing oil and gas from other countries has affected Jordan's economy where now the country is experiencing high external debt and budget deficit. In addition to that, poverty and unemployment rates have also increased in the country.

The relationship between energy consumption and economic growth has been greatly discussed in the last few decades and numerous scholars have attempted to study the causal relationships between energy consumption and economic growth whether the economic growth for the country is represented by gross domestic product, 
national domestic product, income or employment.

In this study, countries that fully rely on other countries for their energy sources such as oil and gas are presented as an example. Further, this study also examines the causality between energy consumption and economic growth and between energy consumption and Islamic banking system performance. There are many studies on the causal relationship between energy consumption and economic growth (Cheng \& Lai, 1997; Aqeel \& Butt, 2001; Narayan \& Popp, 2012) and results indicated that there exists a strong causal relationship between energy consumption and economic growth. However, the results are mixed; some studies concluded a bi-directional causality while some studies documented a unidirectional causality and the rest indicated no causal relation among the variables. However, to the best of the author's belief and knowledge, this study is the first to investigate the causal relationship between energy consumption and Islamic banking system performance.

The organization of this paper is as follows: The next section highlights the literature review and the past studies in the same field; section 3 illustrates the dependent and independent variables; section 4 describes the methodology and data sources; section 5 reports the empirical results and the last section discusses the conclusion, policy implication and further study.

\section{Literature Review}

The causal relationship between energy consumption and economic growth has been the focus of many studies in the last few decades. In this section, the previous studies are classified based on the three directions of the causality test: unidirectional, bidirectional, and no causality relationships among variables. First, the unidirectional causality relationship between energy consumption and economic growth was documented in various developed and developing countries such as the study by Kraft and Kraft (1978) which indicated unidirectional causality running from GNP to energy consumption in the United States. In India, using annual data for the period of 1950-1997, Ghosh (2002) discovered a unidirectional Granger causality from economic growth to electricity consumption. Unidirectional causality relationship from energy consumption to economic growth was also found in some studies such as a study in India by Asafu-Adjaye (2000) which showed unidirectional Granger causality running from energy consumption to GDP, and also unidirectional Granger causality running from energy and price to income in the long run. Additionally, there is also unidirectional causality running from electricity supply to economic growth in Sri Lanka (Morimoto \& Hope, 2004) and thus, Sri Lanka's economic growth is seriously impacted by power shortages. More recent studies that indicated unidirectional causality relationships are the studies by Odhiambo (2009), Tsani (2010), Wang et al. (2011), and Yazdan and Hossein (2012).

There are also many studies that found bi-directional causality relationship between energy consumption and economic growth. For instance, in the study on growth of energy consumption and growth national product in the Taiwan province of China, Hwang et al. (1991) found a bidirectional causality relationship, while the study by Ghali and El-Sakka (2004) based on data from Canada found that the short-run dynamics of variables indicated that Granger's causality is running in two directions between output growth and energy consumption. The study on the causality relationships between energy consumption and economic growth in India indicates that there is bi-directional causality between energy consumption and economic growth (Paul \& Bhattacharya, 2004).

With regard to the third classification which is no causality relationship, among other researchers, Masih and Masih (1997) reported that energy conservation policies may be implemented without leaving any adverse effect on growth and employment. Meanwhile, Jumbe (2004) stated that if both directions show no causality (known as the "neutrality hypothesis) then it suggests that there is no correlation between energy consumption and GDP and thus, the policies of energy conservation may be pursued without adversely impacting the economy. Further, a number of studies found no causality relationship between energy consumption and economic growth. For instance, a study by Yu et al. (1988) indicated that in the United States, there is no relationship between energy and GNP.

In case of Islamic banking, Ahmed et al. (2015) analyzed the relationship between Murabaha and macroeconomic variables using ARDL approach and they found that there is a positive relationship between Murabaha and GDP, FDI and M2.

Nonetheless, the causality relationship between energy consumption and Islamic banking system in order to ascertain if energy consumption leads to Murabaha in Islamic banking system or vice versa, have yet to be addressed by the scholars. 


\section{Variables Description}

\subsection{Gross Domestic Product (GDP) as a Proxy of Economic Growth}

Gross domestic product (GDP) is the variable that has been used in most studies. In other words, the overall market value of all final goods and services produced in a country in a given year has become the indicator of the economic growth and development. An example of the use of GDP can be seen in the study by Yacoubian and Dagher (2012). Meanwhile, the study by Ozun and Cifter (2007) employed gross national product (GNP) which basically gauges the value of goods and services produced by the country's citizens irrespective of of their location, as a proxy of economic growth. In the context of this study, GDP is used as a proxy of Jordan's economic growth. Figure 1 shows the GDP of Jordan for the 1978-2012 period as an indicator for Jordan's economy. For the period of 1978-2012, the annual growth rate of Jordan's GDP achieved a value of $5.8 \%$ and towards the targeted period, the figures show a slight increase. In 2012, Jordan's GDP reached \$31.35 billion albeit global financial crisis, political events, inflation and other challenges faced by countries in the Middle East in general.

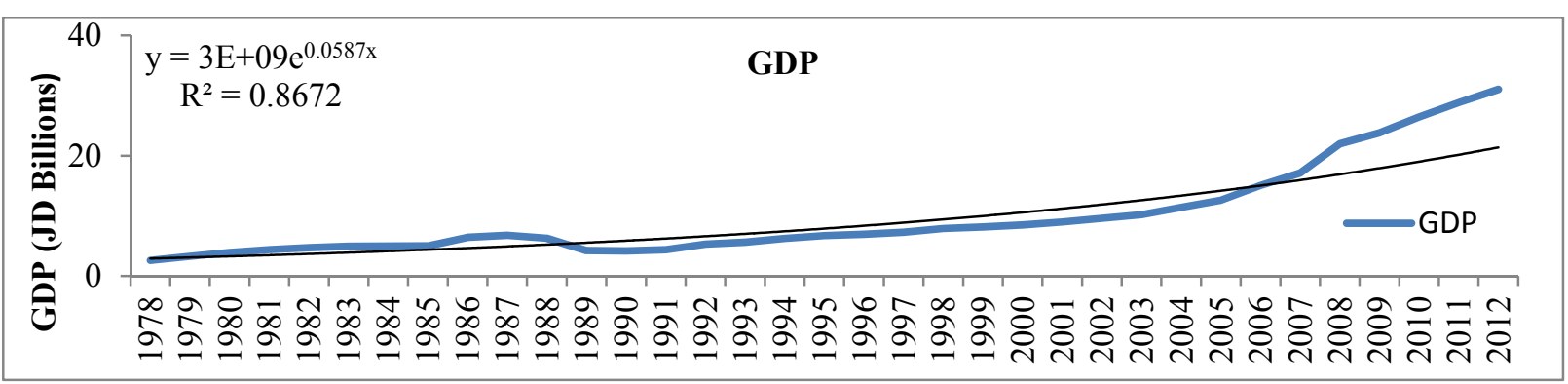

Figure 1. Gross domestic product in Jordan for the 1978-2012 period

Source: The World Bank, Jordanian Development Indicators Databases (2013) available online at: http://data.worldbank.org/country/jordan

\subsection{Murabaha (MU) as a Proxy of Islamic Banking System Performance}

Jordan is one of the first countries in the Middle East to establish Islamic bank offering Sharia compliant operation, services and financial instruments such as Musharaka, Mudaraba and Murabaha. Jordan's first Islamic bank was established in 1978 under the name of Jordan Islamic Bank (JIB).

Islamic banking and finance operate based on Sharia principles which forbid payment or receipt of Riba, a term that is generally misinterpreted as interest (Pryor, 2007), and the most popular and most common mode of Islamic financing is the Murabaha (MU). This mode of Islamic financing is also known as mark up or cost plus financing. Originating from the Arabic word Ribh, which means profits, Murabaha was initially a contract of sale in which a commodity is sold on profit. In this type of contract, the seller has the obligation to inform the buyer his cost price and the profit he is making. After a small modification for application in the financial section, the new Murabaha is now globally the single most popular technique of financing amongst the Islamic banks where an estimate of 80 to 90 percent of financial operations of some Islamic banks belong to this category.

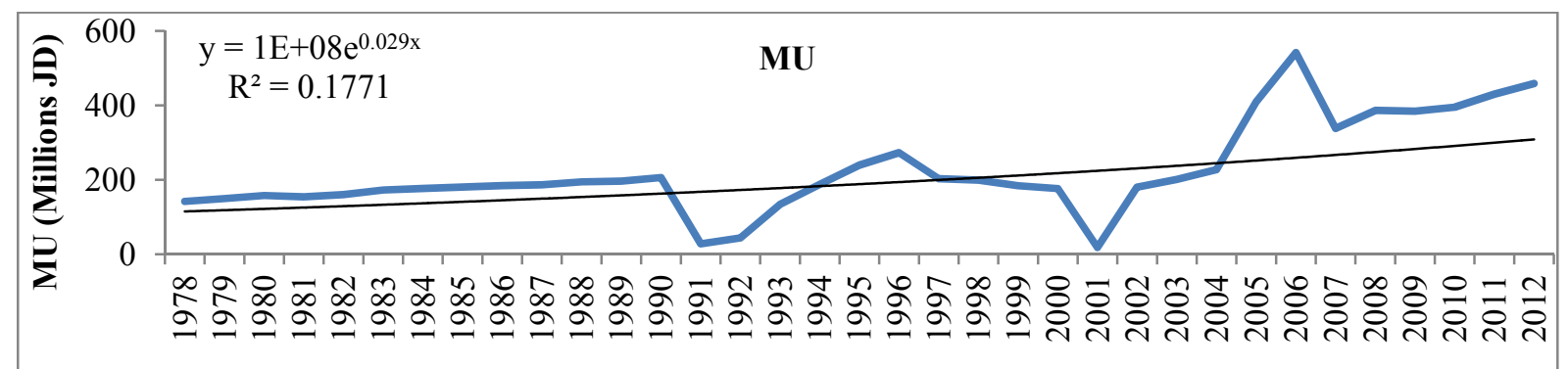

Figure 2. Murabaha in Jordan for the1978-2012 period

Source: Jordan Islamic Bank for Finance and Investment, Annual Reports, 1978-2012. 
Figure 2 illustrates the Murabaha (MU) in JIS for the period 1978-2012. From the figure, MU had reached a yearly growth rate of 3\% \% for the period, and the increasing rate was notable before GFC and during the period of Arab Spring. This shows that global financial crisis and political events also affect Islamic banks. For the current study, MU is used as a proxy of the Islamic banking system.

\subsection{Energy Consumption (EC)}

Unlike its close counterparts, Jordan does not own significant energy resources. As proof, as of January 2014, the Oil \& Gas Journal estimated that Jordan's oil reserves was only at 1 million barrels while the country's natural gas reserves was at slightly more than 200 billion cubic feet (Bcf). However, Jordan could significantly increase its oil reserves by the use of oil shale resources and thus, the country plans to build the first oil shale-fired electricity generation facility in the Middle East after 2017.

Since Jordan has insufficient significant energy resources, the country heavily depends on imports of crude oil, petroleum products, and natural gas to meet its domestic energy demand. As indicated by the government sources, imports of energy for Jordan meet more than $90 \%$ of the country's energy demand, and those imports make up for more than $40 \%$ of the country's budget.

Figure 3 illustrates Jordan's energy consumption for the period of 1987 to 2012 . The annual growth rate is $1.4 \%$. The government statistics showed that in 2012, Jordan's consumption of crude oil and oil products accounted for approximately $88 \%$ of the country's total primary energy demand. However, with regard to the domestic sources of oil and natural gas, only less than $2 \%$ of the demand was met.

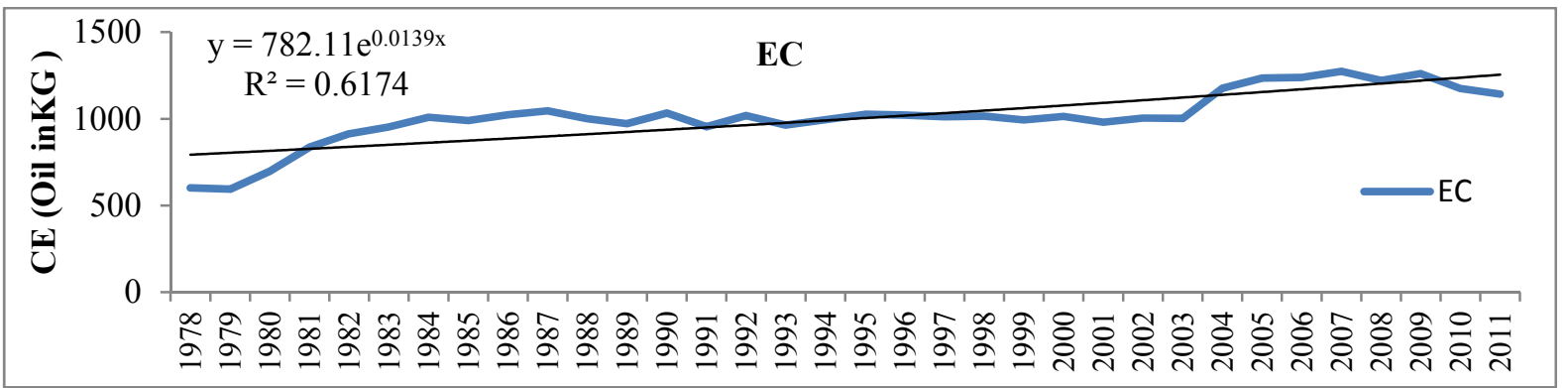

Figure 3. Energy consumption in Jordan for the 1978-2012 period

Source: The World Bank, Jordanian Development Indicators Databases (2013) available online at: http://data.worldbank.org/country/jordan

Energy imports are usually affected by financial crisis and political situation that occur in the exporting countries and since the middle of 1990 s, the political situation in the countries surrounding Jordan (the Middle East) has not been stable especially Iraq and Egypt; this especially refers to Iraq war in 2004 and the Arab Spring since 2010. All these impart great impact to Jordan's energy imports.

\section{Methodology and Data Sources}

The aim of this paper is to analyze the effect of energy consumption on economic growth and the effect of energy consumption on Islamic banking system performance in Jordan over the period 1978-2012. The first step is to perform the empirical analyses related to the study. However, the diagnostic tests have to be conducted to ascertain the adequacy and closeness of fit of the model to the data. As indicated by Pesaran and Pesaran (2009) there are different diagnostic statistics available to estimate the possibility of normality, autocorrelation, hetrosecedasticity for disturbances in a small sample size as well as the appropriateness of the functional form. The current study employs the Augmented Dickey Fuller (ADF) (1987) and the Ng-Perron (2001) to test the stationary for the data while the bounds $F$-statistics test uses for testing the co-integration among the variables. Additionally, the autoregressive distributed lag ARDL approach by Pesaran et al. (2001) also employs to analyze the long-run and short-run relationships between the variables. The data on energy consumption and GDP were gathered from the database of the World Bank database while data on Murabaha were collected from the JIB annual reports (printed copies) for the period of 1978-2012.

However, the ARDL approach for the current models is illustrated in Equation: (1), (2), (3) and (4).

The First Model: 


$$
\begin{gathered}
\Delta L E C_{t}=\beta_{1+} \delta_{I I} L E C_{t-1}+\delta_{12} L G D P_{t-1}+\sum_{t=s}^{h} v_{11} \Delta L E C_{t-s}+\sum_{t=s}^{h} v_{12} \Delta L G D P_{t-s}-\tau_{1} e c m_{t-1}+\varepsilon_{l t} \\
\Delta L G D P_{t}=\beta_{2}+\delta_{21} \Delta L G D P_{t-1}+\delta_{22} L E C_{t-1}+\sum_{t=s}^{h} v_{21} \Delta L G D P_{t-s}+\sum_{t=s}^{h} v_{22} \Delta L E C_{t-s}-\tau_{2} e c m_{t-1}+\varepsilon_{2 t}
\end{gathered}
$$

The Second Model:

$$
\begin{gathered}
\Delta \mathrm{LEC}_{\mathrm{t}}=\beta_{1}+\delta_{11} \mathrm{LEC}_{\mathrm{t}-1}+\delta_{12} \mathrm{LMU}_{\mathrm{t}-1}+\sum_{t=s}^{h} v_{11} \Delta \mathrm{LEC}_{\mathrm{t}-\mathrm{s}}+\sum_{t=s}^{h} v_{12} \Delta \mathrm{LMU}_{\mathrm{t}-\mathrm{s}}-\tau_{1} \mathrm{ecm}_{\mathrm{t}-1}+\varepsilon_{1 \mathrm{t}} \\
\Delta \mathrm{LMU}_{\mathrm{t}}=\beta_{2}+\delta_{21} \Delta \mathrm{LMU}_{\mathrm{t}-1}+\delta_{22} \mathrm{LEC}_{\mathrm{t}-1}+\sum_{t=s}^{h} v_{21} \Delta \mathrm{LMU}_{\mathrm{t}-\mathrm{s}}+\sum_{t=s}^{h} v_{22} \Delta \mathrm{LEC}_{\mathrm{t}-\mathrm{s}}-\tau_{2} \mathrm{ecm}_{\mathrm{t}-1}+\varepsilon_{2 \mathrm{t}}
\end{gathered}
$$

Where, $\beta_{1}$ and $\beta_{2}$ denote the intercept terms while $\delta_{\mathrm{i}}(\mathrm{i}=11, \ldots 22)$ denote the long-run coefficient. $v_{i}(\mathrm{i}=11, \ldots$, 22) represent the short-run coefficient while $\tau_{i}(i=1, \ldots, 2)$ represent the coefficient of error correction terms, i,e., $\left(\mathrm{ecm}_{\mathrm{t}-1}\right) . \varepsilon_{\mathrm{it}}$ represents the error terms. $h$ Indicates the lag length selected. $t$, which denotes the lag order.

\section{Results Analysis}

\subsection{Descriptive Statistics of the Variables}

Table 1 illustrates the descriptive statistics for the variables. As indicated in the table, EC has the highest mean among the variables with the value of 1015 followed by GDP and MU by 22.78 and 2.26 respectively. Further, the Jaque-Bera test, one of the diagnostic tests, indicates there is normality in distribution for the models.

Table 1. Descriptive statistics of the variables

\begin{tabular}{lccc}
\hline & LGDP & LEC & LMU \\
\hline Mean & 22.78 & 1015 & 2.26 \\
Median & 22.63 & 1011 & 1.88 \\
Maximum & 24.15 & 1273 & 5.42 \\
Minimum & 21.67 & 594 & 1813 \\
Std. Dev & 0.64 & 159 & 1.21 \\
Skewness & 0.66 & -0.81 & 0.79 \\
Kurtosis & 2.58 & 4.18 & 3.23 \\
Jaque-Bera & 2.82 & 5.94 & 3.77 \\
Probability & 0.24 & 0.52 & 0.15 \\
\hline
\end{tabular}

Sources: Output of E-Views package, version 7.2.

\subsection{Stationary Tests}

Verifying the stationarity of the data series is the second step of the analysis and for this purpose the ADF and Ng-Perron tests were employed. The unit root property of the data series is vital for the analyses of causality. The non-stationary variables can be made stationary by differencing the number of differencing $(\mathrm{d})$ required so that the order of integration $1(\mathrm{~d})$ can be identified by the series stationarity.

As shown in Table 2.1 and 2.2 the results of unit root tests indicate that the null hypothesis of unit root for EC,

\begin{tabular}{|c|c|c|c|c|c|c|}
\hline \multirow{2}{*}{ Integration } & \multirow{2}{*}{ Variables } & \multirow{2}{*}{ ADF test } & \multirow{2}{*}{ Ng- Perron test } & \multicolumn{3}{|c|}{ ADF asymptotic critical values } \\
\hline & & & & $1 \%$ & $5 \%$ & $10 \%$ \\
\hline \multirow{4}{*}{$I(1)$} & $\Delta$ LGDP & $3.72 * *$ & $6.89^{* * *}$ & 4.33 & 3.58 & 3.22 \\
\hline & $\triangle \mathrm{LEC}$ & $5.60 * * *$ & $5.58 * *$ & \multicolumn{3}{|c|}{ Ng-P asymptotic critical values } \\
\hline & & & & $1 \%$ & $5 \%$ & $10 \%$ \\
\hline & & & & 4.03 & 5.48 & 6.67 \\
\hline
\end{tabular}
GDP and MU was not rejected at levels. However, at first differentiation, all series were found to be stationary and integrated at the order of one 1(1), thus, from this point the co-integration can be employed as the next step.

Table 2.1. Stationary tests for LGDP model 
Table 2.2. Stationary tests for LMU model

\begin{tabular}{|c|c|c|c|c|c|c|}
\hline \multirow{2}{*}{ Integration } & \multirow{2}{*}{ Variables } & \multirow{2}{*}{$\mathrm{ADF}$ test } & \multirow{2}{*}{ Ng- Perron test } & \multicolumn{3}{|c|}{ ADF asymptotic critical values } \\
\hline & & & & $1 \%$ & $5 \%$ & $10 \%$ \\
\hline \multirow{4}{*}{$I(1)$} & $\Delta \mathrm{LMU}$ & $6.30^{* * *}$ & $5.63 * *$ & 4.33 & 3.58 & 3.22 \\
\hline & $\triangle \mathrm{LEC}$ & $5.60 * * *$ & $5.58^{* *}$ & \multicolumn{3}{|c|}{ Ng-P asymptotic critical values } \\
\hline & & & & $1 \%$ & $5 \%$ & $10 \%$ \\
\hline & & & & 4.03 & 5.48 & \\
\hline
\end{tabular}

As the order of integration tests was completed with desirable results, a co-integration test is conducted next in order to ensure that co-integration exists among the variables before the researchers could analyze the long-run and short-run relationships and conclusively ascertain if causality relation between GDP and EC, UM and EC exists.

Table 3 presents the results of the bounds F-statistics test which indicate the co-integration of all variables and thus, the equilibrium relationships in the models can be analyzed as the next step.

Table 3. Co-integration test results for LGDP and LMU model

\begin{tabular}{|c|c|c|c|c|c|}
\hline \multicolumn{6}{|c|}{ Bound F-statistics critical values with Intercept } \\
\hline \multicolumn{2}{|c|}{$1 \%$ significance level } & \multicolumn{2}{|c|}{$5 \%$ significance level } & \multicolumn{2}{|c|}{$10 \%$ significance level } \\
\hline $\mathrm{I}(0)$ & $I(1)$ & $I(0)$ & $I(1)$ & $I(0)$ & $\mathrm{I}(1)$ \\
\hline 5.15 & 5.53 & 3.47 & 4.33 & 2.84 & 3. 62 \\
\hline \multicolumn{6}{|c|}{ OLS Bound F-statistics values: } \\
\hline Model & & \multicolumn{2}{|c|}{ Calculated F-statistics } & \multicolumn{2}{|c|}{ Decision } \\
\hline LGDP & & \multicolumn{2}{|c|}{$6.55 * * *$} & \multicolumn{2}{|c|}{ Co-integrated } \\
\hline LEC & & \multicolumn{2}{|c|}{$5.71 * * *$} & \multicolumn{2}{|c|}{ Co-integrated } \\
\hline Model & & \multicolumn{2}{|c|}{ Calculated F-statistics } & \multicolumn{2}{|c|}{ Decision } \\
\hline LMU & & \multicolumn{2}{|c|}{$9.37 * * *$} & \multicolumn{2}{|c|}{ Co-integrated } \\
\hline LEC & & \multicolumn{2}{|c|}{$5.89 * * *$} & \multicolumn{2}{|c|}{ Co-integrated } \\
\hline
\end{tabular}

Note. (1) The bound F-statistic critical values were obtained from Narayan (2005) statistical tables. (2) ***,**,* represent significance at the $1 \%, 5 \%$ and $10 \%$ levels, respectively. (3) The output of OLS Bound F-statistics values were extracted from the Micro-fit econometric software package version 4.1 .

\subsection{Long-Run and Short-Run Results}

As shown in Table 4, $\mathrm{LEC}_{\mathrm{t}}$ has positive association with the $\mathrm{LGDP}_{\mathrm{t}}$ model in the short-run with $10 \%$ significance level also it is positively related to the $\mathrm{LGDP}_{t}$ model in the long-run at the $10 \%$ significance level. As indicated by the long-run result, the $10 \%$ increase in $\mathrm{LEC}_{t}$ will increase the $\mathrm{LGDP}_{\mathrm{t}}$ model by $0.34 \%$. The findings of the LGDP $_{t}$ model show consistency with the findings of Ouedrago (2012) who studied the long-run relationships between GDP and EC among 15 African countries. The error correction term $E C M_{t-1}$ carries the expected negative sign at $1 \%$ significance level, which implies that there is a an adjustment mechanism, which forces the dependent variable to the equilibrium.

Table 4. Equilibrium relationships analysis for the LGDPt model

\begin{tabular}{|c|c|c|c|c|c|}
\hline \multicolumn{6}{|c|}{33 observation used for estimating the long-run relationships in the LGDP $_{t}$ Model } \\
\hline Variables & Coefficients & Standard errors & T-ratios & P-values & Significance Levels \\
\hline Intercept term & 21.56 & 11.28 & 1.91 & 0.06 & $10 \%$ \\
\hline $\mathrm{LEC}_{\mathrm{t}-1}$ & 0.34 & 0.19 & 1.8 & 0.08 & $10 \%$ \\
\hline \multicolumn{6}{|c|}{33 observations for estimating the short-run relationships and $\mathrm{ecm}_{\mathrm{t}-1}$ in the $\Delta \mathrm{LGDP}_{\mathrm{t}}$ Model. } \\
\hline \multicolumn{6}{|c|}{ The selection of ARDL $(1,0)$ approach is based on SBC. } \\
\hline Variables & Coefficients & Standard errors & T-ratios & P-values & Significance Levels \\
\hline Intercept term & 11.08 & 4.03 & 2.75 & 0.01 & $1 \%$ \\
\hline$\Delta \mathrm{LEC}_{\mathrm{t}}$ & 0.29 & 0.16 & 1.83 & 0.07 & $10 \%$ \\
\hline $\mathrm{Ecm}_{\mathrm{t}-1}$ & -0.28 & 0.06 & -4.3 & 0 & $1 \%$ \\
\hline
\end{tabular}




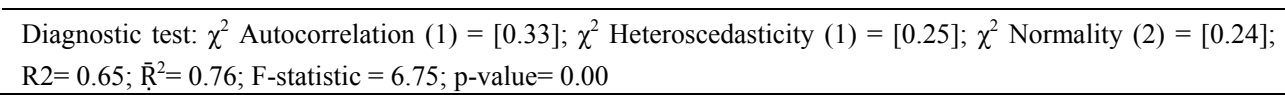

Note. (1) Figure in parentheses denotes the p-values of F-statistics. (2) Figure in brackets denotes the p-values of the chi-square $\left(\chi^{2}\right)$. (3) SBC presents Schwarz Bayesian Criterion that calculates the lag length and order. (4) The output was sourced from the Micro-fit econometric software package version 4.1

Table 5 reveals the equilibrium relationships analysis for the $\mathrm{LEC}_{\mathrm{t}}$ model, the results show that $\mathrm{LGDP}_{\mathrm{t}}$ is negatively related to the $\mathrm{LEC}_{\mathrm{t}}$ model in the short-run while positively related in the long-run at $5 \%$ significance level. As indicated by the findings. The $E C M_{t-1}$ coefficient is negative and highly significant, the coefficient of $(-0.27)$ suggests that the speed of the adjustment back to equilibrium is not very fast. For instance, only $27 \%$ of the adjustment is completed in a year due to a short-run adjustment.

Table 5. Equilibrium relationships analysis for the $\mathrm{LEC}_{\mathrm{t}}$ model

\begin{tabular}{lccccc}
\hline \multicolumn{5}{c}{33 observation used for estimating the long-run relationships in the LEC $_{\mathrm{t}}$ Model } \\
\hline Variables & Coefficients & Standard errors & T-ratios & P-values & Significance Levels \\
Intercept term & 36.81 & 13.73 & 2.68 & 0.01 & $1 \%$ \\
LGDP $_{\mathrm{t}-1}$ & -0.19 & 0.1 & -1.92 & 0.06 & $10 \%$ \\
\hline
\end{tabular}

33 observations for estimating the short-run relationships and $\mathrm{ecm}_{\mathrm{t}-1}$ in the $\Delta \mathrm{LEC}_{\mathrm{t}}$ Model. The selection of ARDL $(1,0)$ approach is based on SBC.

\begin{tabular}{llcccc}
\hline Variables & Coefficients & Standard errors & T-ratios & P-values & Significance Levels \\
Intercept term & 24.52 & 9.25 & 2.65 & 0.01 & $1 \%$ \\
$\Delta \mathrm{LGDP}_{\mathrm{t}}$ & 0.26 & 0.12 & 2.18 & 0.06 & $5 \%$ \\
Ecm $_{\mathrm{t}-1}$ & -0.27 & 0.08 & -3.22 & 0 & $1 \%$ \\
\hline
\end{tabular}

Diagnostic test: $\chi^{2}$ Autocorrelation $(1)=[0.35] ; \chi^{2}$ Heteroscedasticity $(1)=[0.27] ; \chi^{2}$ Normality $(2)=[0.28]$;

$$
\mathrm{R}^{2}=0.70 ; \overline{\mathrm{R}}^{2}=0.68 ; \text { F-statistic }=6.91 ; \mathrm{p} \text {-value }=0.00
$$

Note. (1) Figure in parentheses denotes the p-values of F-statistics. (2) Figure in brackets denotes the p-values of the chi-square $\left(\chi^{2}\right)$. (3) SBC presents Schwarz Bayesian Criterion that calculates the lag length and order. (4) The output was sourced from the Micro-fit econometric software package version 4.1 .

However, Table 6 shows that $\mathrm{LEC}_{\mathrm{t}}$ is positively related to the $\mathrm{LMU}_{\mathrm{t}}$ model in the short-run and long-run at the $10 \%$ and $5 \%$ significance level, respectively. As indicated by the findings, a $10 \%$ rise in $\mathrm{LEC}_{\mathrm{t}}$ will increase the $\mathrm{LMU}_{\mathrm{t}}$ model by $56 \%$ in the short-run and $38 \%$ in the long-run, and vice versa. The table also shows that the lagged error correction term $E C M_{t-1}$ has the expected negative sign with $1 \%$ significance level and the coefficient is $(-0.35)$ indicating there is a quick adjustment to disequilibrium in the short-run.

Table 6. Equilibrium relationships analysis for the $\mathrm{LMU}_{\mathrm{t}}$ model

\begin{tabular}{|c|c|c|c|c|c|}
\hline \multicolumn{6}{|c|}{33 observations used to estimate the long-run relationships in the $\mathrm{LMU}_{\mathrm{t}}$ Model } \\
\hline Variables & Coefficients & Standard errors & T-ratios & P-values & Significance Levels \\
\hline Intercept term & -6.28 & 2.35 & -2.67 & 0.01 & $1 \%$ \\
\hline $\mathrm{LEC}_{\mathrm{t}-1}$ & 0.38 & 0.22 & 1.72 & 0.09 & $10 \%$ \\
\hline \multicolumn{6}{|c|}{33 observations to estimate the short-run relationships and $\mathrm{ecm}_{\mathrm{t}-1}$ in the $\Delta \mathrm{LMU}_{\mathrm{t}}$ Model } \\
\hline \multicolumn{6}{|c|}{ The selection of ARDL $(1,0)$ approach is based on SBC. } \\
\hline Variables & Coefficients & Standard errors & T-ratios & P-values & Significance Levels \\
\hline Intercept term & -2.9 & 1.27 & 2.72 & 0.03 & $5 \%$ \\
\hline$\Delta \mathrm{LEC}_{\mathrm{t}}$ & 0.56 & 0.24 & 2.33 & 0.03 & $5 \%$ \\
\hline $\mathrm{Ecm}_{\mathrm{t}-1}$ & -0.35 & 0.12 & -2.91 & 0 & $1 \%$ \\
\hline \multicolumn{6}{|c|}{$\begin{array}{c}\text { Diagnostic test: } \chi^{2} \text { Autocorrelation }(1)=[0.65] ; \chi^{2} \text { Heteroscedasticity }(1)=[0.21] ; \chi^{2} \text { Normality }(2)=[0.15] ; R^{2}= \\
0.62 ; \bar{R}^{2}=0.42 ; \text { F-statistic }=26.19 ; p \text {-value }=0.00\end{array}$} \\
\hline
\end{tabular}

Note. (1) Figure in parentheses represents the p-values of F-statistics. (2) Figure in brackets denotes the p-values of the chi-square $\left(\chi^{2}\right)$. (3) SBC presents Schwarz Bayesian Criterion that calculates the lag length and order. (4) The output was sourced from the Micro-fit econometric software package version 4.1. 
Table 7 represents the short-run and long-run relationships analysis between $\mathrm{LMU}_{\mathrm{t}}$ and $\mathrm{LEC}_{\mathrm{t}}$. The results show that the $\mathrm{LMU}_{\mathrm{t}}$ is positively associated to the $\mathrm{LEC}_{\mathrm{t}}$ model in short-run and long-run at $10 \%$ significance level. For the error correction term $E C M_{t-1}$, the results show that there is a correct sign with coefficient $(-0.34)$ and significance level at $1 \%$, that means the magnitude of the coefficient lagged error term is $34 \%$ speed to return back the dependent variable to the equilibrium.

Table 7. Equilibrium relationships analysis for the $\mathrm{LEC}_{\mathrm{t}}$ model

\begin{tabular}{|c|c|c|c|c|c|}
\hline \multicolumn{6}{|c|}{33 observations used to estimate the long-run relationships in the $\mathrm{LEC}_{\mathrm{t}}$ Model } \\
\hline Variables & Coefficients & Standard errors & T-ratios & P-values & Significance Levels \\
\hline Intercept term & 22.1 & 5.25 & 4.21 & 0 & $1 \%$ \\
\hline $\mathrm{LMU}_{\mathrm{t}-1}$ & 0.45 & 0.23 & 1.95 & 0.06 & $10 \%$ \\
\hline \multicolumn{6}{|c|}{33 observations to estimate the short-run relationships and $\mathrm{ecm}_{\mathrm{t}-1}$ in the $\Delta \mathrm{LMU}_{\mathrm{t}}$ Model } \\
\hline Variables & Coefficients & Standard errors & T-ratios & P-values & Significance Levels \\
\hline Intercept term & 15.5 & 5.75 & 2.69 & 0.01 & $1 \%$ \\
\hline$\Delta \mathrm{LMU}_{\mathrm{t}}$ & 0.22 & 0.12 & 1.84 & 0.07 & $10 \%$ \\
\hline $\mathrm{Ecm}_{\mathrm{t}-1}$ & -0.34 & 0.07 & -4.52 & 0 & $1 \%$ \\
\hline
\end{tabular}

Note. (1) Figure in parentheses represents the p-values of F-statistics. (2) Figure in brackets denotes the p-values of the chi-square $\left(\chi^{2}\right)$. (3) SBC presents Schwarz Bayesian Criterion that calculates the lag length and order. (4) The output was sourced from the Micro-fit econometric software package version 4.1 .

\subsection{Granger Causality Results}

The results of the Granger causality test and the null hypothesis of causality relationships among the variables are shown in Table 8. As indicated in the results, if the $P$-value is less than the $5 \%$ level of significance, the null hypothesis will be rejected. The results indicate that there is unidirectional causality relationship between GDP and EC and the direction runs from LGDP to EC while there is no causality relationship running from EC to GDP. The LMU model also shows similar results where unidirectional causality exists between LMU and LEC and the direction runs from LMU to LEC but not vice versa. Simply put, the GDP and MU affect EC, but EC has no effect on GDP and MU. These findings are consistent with past studies such as the study by Paul et al. (2004) which examined the causality relationship between energy consumption and Economic growth in India.

Table 8. Granger causality relationships among the variables

\begin{tabular}{lccc}
\hline Causality Direction & F-statistic & P-value & Decision \\
\hline LGDP Model & & & \\
LGDP $\rightarrow$ LEC & 0.87 & 0.04 & Unidirectional Causality \\
LEC $\neq$ LGDP & 1.12 & 0.33 & No Casualty \\
LUM Model & & & \\
LUM $\rightarrow$ LEC & 1.78 & 0.03 & Unidirectional Causality \\
LEC $\neq$ LUM & 0.96 & 0.39 & No Causality \\
\hline
\end{tabular}

Note. The $(\rightarrow, \leftrightarrow \& \neq)$ represent the unidirectional, bidirectional and no Granger causality respectively. Sources: Output of E- Views Package, version 7.2.

\section{Conclusion, Policy Implication and Further Research}

This study is an empirical study and the main objective is to examine the causal relationship between economic growth and energy consumption as well between Islamic banking system performance and energy consumption in Jordan, the study used GDP as a proxy of the economic growth and Murabaha as a proxy of the Islamic banking system performance for a country that imports oil, over the period of 1978-2012. Moreover, another main objective is to explore how far the Islamic banking system direction from the economic growth direction when affected by some macroeconomic variables such as energy consumption. In this study, the annual times series data were used and by using the ARDL approach, the long-run and short-run relationships among the 
variables were examined. The data then went through the diagnostic tests and stationary tests and passed. The bounds F-statistics test was also employed in this study to ascertain the co-integration between the variables while the Granger causality test was used to identify the causality relationships and the causal direction between the variables. Further, the results of the ADF and Ng-Perron indicate stationarity of variables at $I(1)$, and based on the result of F-bound test, the variables are also co-integrated. Further, both models also show positive relationships between the variables in the long run, and as indicated by the Granger causality test, there is unidirectional causality from GDP to EC also from MU to EC but not vice versa. Another main finding is that Islamic banking system direction moves with the same economic growth direction in Jordan when affected by the energy consumption. The analysis results of this study indicate that there is a positive correlation between GDP, energy consumption and Islamic Banking system performance. That means, when the GDP which concerned as the main indicator for economic growth raises, the energy consumption especially those used in the productivity processes will increase. In the other side, the Islamic banking system performance as one of the main economic cycle in Jordan will be improved.

These results are in line with the findings of Kraft and Kraft (1978) and Ghosh (2002) who documented in their study a unidirectional causality from economic growth to energy consumption.

This study illustrated one of the rational relationships between economic growth and energy consumption and it also indicated that economic growth causes the increase in energy consumption. As such, the policy makers in Jordan's government as well as the Islamic banking system should be more aware of this phenomenon. Also, they should motivate the industrial and services sectors by supporting their development through channeling substantial amount of energy into these sectors. Further study could be focused on the relationships between other macroeconomic variables on the other Islamic banking instruments such as Musharaka and Mudaraba.

\section{References}

Ahmed, N., Yazis, M., \& Oudat, M. S. (2015). Analysing Long-Run and Short-Run Relationships between Macroeconomic Variables and Murabaha to the Purchase-Order: Evidence from Jordanian Islamic Bank. International Journal Economics and Finance, 7(2), 168-177. http://dx.doi.org/10.5539/ijef.v7n2p168

Aqeel, A., \& Butt, M. S. (2001). The Relationship between Energy Consumption and Economic Growth in Pakistan. Asia-Pacific Development Journal, 8(2), 101-126.

Asafu-Adjaye, J. (2000). The Relationship between Energy Consumption, Energy Prices and Economic Growth: Time Series Evidence from Asian Developing Countries. Energy Economics, 22(6), 615-625. http://dx.doi.org/10.1016/S0140-9883(00)00050-5

Cheng, B. S., \& Lai, W. L. (1997). An Investigation of Co-integration and Causality between Energy Consumption and Economic Activity in Taiwan. Energy Economics, 19, 435-444. http://dx.doi.org/10.1016/S0140-9883(97)01023-2

Engle, R., \& Granger. C. (1987). Co-integration and Error Correction Representation, Test and Telling. Econometrica, 55(2), 251-276. http://dx.doi.org/10.2307/1913236

Ghali, K. H., \& El-Sakka, M. I. T. (2004). Energy Use and Output Growth in Canada: A Multivariate $\begin{array}{lllll}\text { Co-integration } & \text { Analysis. } & \text { Energy } & \text { 225-238. }\end{array}$ http://dx.doi.org/10.1016/S0140-9883(03)00056-2

Ghosh, S. (2002). Electricity consumption and economic growth in India. Energy Policy, 30(2), 125-129. http://dx.doi.org/10.1016/S0301-4215(01)00078-7

Hwang, D. B., \& Gun-Burel, K. (1991). The causal relationship between energy and GNP: The case of Taiwan Province of China. Journal of Energy and Development, 16, 219-226.

Jordan Islamic Bank. (n.d.). Annual Reports 1978-2012, printed copies.

Jumbe, C. B. L. (2004). Co-integration and Causality between Electricity Consumption and GDP: Empirical Evidence from Malawi. Energy Economics, http://dx.doi.org/10.1016/S0140-9883(03)00058-6

Kraft, J., \& Kraft, A. (1978). On the Relationship between Energy and GNP. Journal of Energy and Development, 3, 401-403.

Masih, A. M. M., \& Masih, R. (1996). Energy Consumption, Real Income and Temporal Causality: Results from a Multi-Country Study based on Co-integration and Error-Correction Modelling Techniques. Energy Economics, 18(3), 165-183. http://dx.doi.org/10.1016/0140-9883(96)00009-6 
Morimoto, R., \& Hope, C. (2004). Impact of electricity supply on economic growth in Sri Lanka. Energy Economics, 26(1), 77-85. http://dx.doi.org/10.1016/S0140-9883(03)00034-3

Narayan, P. K., \& Popp, S. (2012). The energy consumption-real GDP nexus revisited: Empirical evidence from 93 countries. Economic Modelling, 29(2), 303-308. http://dx.doi.org/10.1016/j.econmod.2011.10.016

Ng, S., \& Perron, P. (2001). LAG Length Selection and the Construction of Unit Root Tests with Good Size and Power. Econometrica, 69(6), 1519-1554. http://dx.doi.org/10.1111/1468-0262.00256

Odhiambo, N. M. (2009). Energy consumption and economic growth nexus in Tanzania: An ARDL bounds testing approach. Energy Policy, 37(2), 617-622. http://dx.doi.org/10.1016/j.enpol.2008.09.077

Ouedraogo, N. S. (2013). Energy Consumption and Economic Growth: Evidence from the Economic Community of West African States (ECOWAS). Energy Economics, 36, 637-647. dx.doi.org/10.1016/j.eneco.2012.11.011

Ozun, A., \& Cifter, A. (2007). Multi-Scale Causality between Energy Consumption and GNP in Emerging Markets: Evidence from Turkey. Investment Management and Financial Innovations, 4(2), 60-70. Retrieved from http://www.businessperspectives.org/journals_free/imfi/2007/imfi_en_2007_02_Ozun.pdf

Paul, S., \& Bhattacharya, R. N. (2004). Causality between energy consumption and economic growth in India: A note on conflicting results. Energy Economics, 26(6), 977-983. http://dx.doi.org/10.1016/S0301-4215(01)00078-7

Pesaran, M. H., \& Pesaran, B. (1997). Working with Micro-fit 4.0: An interactive econometric software package (DOS and Windows versions). Oxford: Oxford University Press.

Pesaran, M. H., Shin, Y., \& Smith, R. J. (2001). Bounds testing approach to the analysis of level relationships. Journal of Applied Econometrics, 16(3), 289-326. http://dx.doi.org/10.1002/jae.616

Pryor, F. L. (2007). The economic impact of Islam on developing countries. World Development, 35(11), 1815-1835. http://dx.doi.org/10.1016/j.worlddev.2006.12.004

Tsani, S. Z. (2010). Energy consumption and economic growth: A causality analysis for Greece. Energy Economics, 3(3), 582-590. http://dx.doi.org/10.1016/j.eneco.2009.09.007

Wang, S. S., Zhou, D. Q., Zhou, P., \& Wang, Q. W. (2011). $\mathrm{CO}_{2}$ emissions, energy consumption and economic growth in China: A panel data analysis. Energy Policy, 39(9), 4870-4875. http://dx.doi.org/10.1016/j.enpol.2011.06.032

Yacoubian, T., \& Dagher, L. (2012). The Causal Relationship between Energy Consumption and Economic Growth in Lebanon. Energy Policy, 50, 795-801. http://dx.doi.org/10.1016/j.enpol.2012.08.034

Yazdan, G. F., \& Hossein, S. S. M. (2012). Causality between oil consumption and economic growth in Iran: An ARDL testing approach. Asian Economic and Financial Review, 2(6), 606-614. Retrieved from http://www.aessweb.com/pdf-files/Aefr\%20pp.\%20606-614.pdf

\section{Copyrights}

Copyright for this article is retained by the author(s), with first publication rights granted to the journal.

This is an open-access article distributed under the terms and conditions of the Creative Commons Attribution license (http://creativecommons.org/licenses/by/3.0/). 